\title{
Origin of the hydrate bound gases in the Juhugeng Sag, Muli Basin, Tibetan Plateau
}

\author{
Shiming Liu ${ }^{1,2}$ (1) Furong $\operatorname{Tan}^{3} \cdot$ Ting Huo $^{2} \cdot$ Shuheng Tang ${ }^{1} \cdot$ Weixiao Zhao $^{4} \cdot$ \\ Haide Chao ${ }^{5}$
}

Received: 15 June 2019/Revised: 5 September 2019/Accepted: 4 November 2019/Published online: 20 November 2019

(C) The Author(s) 2019

\begin{abstract}
The Juhugeng Sag, located in northwest of the Muli Basin, Tibetan Plateau, has been investigated for coal and petroleum resources during the past several decades. There have been successful recoveries of gas hydrates during recent years from the Middle Jurassic Yaojie Formation that offer insight into the origin of the hydrocarbon gases from the complex sag feature. This study examines the organic geochemical and stable carbon isotopic characteristics of shale and coal samples from the Middle Jurassic Yaojie Formation of the Juhugeng Sag, as well as compares with carbon isotopes, gas amounts and components of hydrate-bound gas. A total of 19 samples from surface mining, including 12 samples of black shale and 7 samples of coal, were analysed using a micro-photometer, a gas chromatograph, Rock-Eval and isotope methods. All the shale samples contained $100 \%$ type I kerogen, and the random vitrinite reflectance values vary from $0.65 \%$ to $1.32 \%$ and achieve thermal pyrolysis phase. Isotope values of methane $\left(\delta^{13} \mathrm{C}\right.$ ranging from $-52.6 \%$ to $-39.5 \%$ and $\delta \mathrm{D}$ ranging from $-285 \%$ to $-227 \%$ ) in the hydrate bound gases suggest that the methane originates mainly from thermogenic contributions. It is proposed that ethane from the gas hydrate is thermogenic-produced, and this conjecture is supported by the fact that most of the gas hydrate also contains more than $30 \%$ of thermogenic $\mathrm{C}_{2+}$ hydrocarbons and is similar to structure II hydrate. Carbon isotope data from the gas hydrates show a positive carbon isotope series $\left(\delta^{13} \mathrm{C}_{1-}\right.$ $<\delta^{13} \mathrm{C}_{2}<\delta^{13} \mathrm{C}_{3}$ ), with ethane $\delta^{13} \mathrm{C}$ values being lighter than $-28.5 \%$, as high consistency with source rocks from the Jurassic period indicate thermal oil-prone gas. A model of the accumulation of gas hydrate is plotted. However, the gaseous sources of gas hydrates may be a subject for more research.
\end{abstract}

Keywords Muli Basin $\cdot$ Stable carbon isotopes $\cdot$ Gas hydrate $\cdot$ Gas source $\cdot$ Alkane gas

Shiming Liu

liushimingstand@163.com

1 School of Energy Resource, China University of Geosciences, Beijing 100083, China

2 Qinghai Institute of Coal Geological Prospecting, Xining 810001, China

3 Aerial Photogrammetry and Remote Sensing Center, China National Administration of Coal Geology, Xi' an 710199, China

4 The Second Exploration Institute of Geology in Qinghai Province, Xining 810003, China

5 The Fourth Exploration Institute of Geology in Qinghai Province, Xining 810008, China

\section{Introduction}

Gas hydrates have become a very promising source of energy this century due to being clean, vast resources with a high energy density as well as are considered as an alternative energy in the future (Sloan and Koh 2008; Zhang et al. 2015; Li et al. 2016). Large amounts of methane, the primary component of natural gas, occur in the form of solid gas hydrate along continental margins and in permafrost sediments, where temperature and pressure are suitable for gas hydrate (Sloan 1998; Buffett 2000; Collett et al. 2009; Li et al. 2016). Hydrates in permafrost regions which is located primarily in high latitude areas, e.g., Canada's Mackenzie Delta, the Northern slope of Alaska (USA) and Russia's west Siberia (Dallimore et al. 
1995; Collett et al. 2011; Nandanwar et al. 2016). In China, the hydrates in tundra areas are mainly distributed in the Tibetan Plateau and the Mohe region (Zhu et al. 2009; Li et al. 2016). Two geometry structures (I and II) of gas hydrates have been found since about 1952 and the third structure ( $\mathrm{sH}$ ) has been recognized in the Gulf of Mexico (Sassen and MacDonald 1994). Structure I is the most common form, which includes more than $99 \%$ methane and trace amounts of ethane (Sloan 1998). Structure II and structure $\mathrm{sH}$ hydrates, which are generally characterized by containing significant quantities $(>1 \%)$ of $\mathrm{C}_{2}-\mathrm{C}_{5}$ hydrocarbons originated from thermal pyrolysis of fossil organic matter (i.e., kerogen) or oil (Brooks et al. 1984; Sassen and MacDonald 1994).

Both microbial methane hydrate and thermogenic gas hydrate are significant elements of the global carbon pool. The bulk of gas hydrate occurrences thus far documented involve microbial methane (structure I) (Milkov 2005). According to previous literature, the Gulf of Mexico (Brooks et al. 1984), northern Cascadia Margin (Pohlman et al. 2005) and the southern summit of Hydrate Ridge offshore Oregon have been found that thermogenic gas hydrates (Milkov et al. 2005). Understanding the source of gas hydrates is necessary for evaluating the resource, climate change and geohazard potential of gas hydrates. Although much research has focused on topography, oil and gas resources evaluation, coal exploration and extensive seismic investigation of the geological setting in Muli Basin, a series of geochemical and geological characteristics of gas hydrate has been carried out in recent years (Zhu et al. 2009; Lu et al. 2010). A series of achievements on the gas hydrates, such as their molecular and isotopic composition, microbiology population, seismic activity features and log response, have been gained (Wang et al. 2009; Zhu et al. 2010; Lu et al. 2010; Huang et al. 2016). The origin of the hydrate bound gases in Juhugeng Sag has been a subject of discussion (Zhu et al. 2010; Cao et al. 2009; Wang et al. 2014; Lu et al. 2010, 2013; Huang et al. 2016; Tan et al. 2017). However, various origin types of gas hydrate have been reported, previous studies were focused on some specific aspect. For example, Wang et al. (2009) and Cao et al. $(2009,2012)$ believe that the gases come from the Middle Jurassic Yaojie Formation coalbed methane and its adjacent carbon mudstone gas. It was reported that the gases are oil-prone, coming from the Triassic or deeper shale gas (Lu et al. 2010, 2013; Huang et al. 2016), while some others considered that the gas sources are a mixture of coal methane and oil-prone gas (Zhang et al. 2016; Cheng et al. 2016). Furthermore, Tan et al. (2017) and Dai et al. (2017) compared the data of coal and oil shale with hydrates, considered that the gases are oil-prone and from shale gas of Yaojie Formation. However, the data about gas hydrate was collected only partially and they did not consider the contributions of $\delta^{13} \mathrm{C}$ of carbon dioxide and $\delta \mathrm{D}$, and didn't plot a model of the accumulation of gas hydrate. As so far, they are not consistent with each other on the genetic types of alkane gases. As a result, there are some advances that still need to be made to establish the provenance of gas hydrates.

In this paper we present the geochemical information and thorough description of stable isotopic $\left(\delta^{13} \mathrm{C}\right.$ and $\left.\delta \mathrm{D}\right)$ composition of hydrate-bound gas, as well as shale gas and coalbed methane, collected on the Juhugeng Sag. By comparing data from coal methane, shale gases and gas hydrates, we hope to gain insight into the origin of gas hydrates.

\section{Geology conditions and samples preparation}

\subsection{Geology conditions}

The Muli Basin is located in the southern-middle Qilian block, which lies between the Paleo-Asian and the Tethys structural domain (Fig. 1). The height of the Muli Basin reaches $4100-4300 \mathrm{~m}$ above sea level, and the annual average temperature is $-5.1{ }^{\circ} \mathrm{C}$. Its permafrost is widely developed with an average thickness of $80 \mathrm{~m}$, and the thickness of permafrost in some areas is greater than $100 \mathrm{~m}$.

The Muli Basin is characterized by a special regional geological setting and evolutionary history (Sun et al. 2000). The basin experienced the pre-carboniferous paleo continental craton evolution stage, the Carboniferous-Triassic new-continental craton evolution stage and the stage of evolution of the residual basin of the Jurassic-Quaternary period (Huang 1996). Furthermore, the residual basin evolution stage is composed of three sub-stages. The first one is a fault subsidence sedimentary stage taking place in the Jurassic, the second is a Cretaceous-Paleogene uplift and erosion phase, and the third one occurred after the Pliocene epoch thrust belt period. Thus, these events were responsible for leading to the basin's present-day geological structure.

The coal layers of the Jurassic period overlie those of the Triassic period via an unconformity. The Jurassic consists of the Lower Jurassic Daxigou, Middle Jurassic Yaojie and Upper Jurassic Xiangtang Formations. The largest part of the gas hydrates is distributed in the Upper Yaojie Formation at the depth of 130-500 m under the permafrost layer, which consists of a mudstone, kerogen shale, siltstone and medium sandstone lithology ( $\mathrm{Lu}$ et al. 2010) (Fig. 1). It is interesting that evidences of oil and gas (EOG) were found in some boreholes (Lu et al. 2013; Cheng et al. 2016), which is consistent with the gas hydrate 

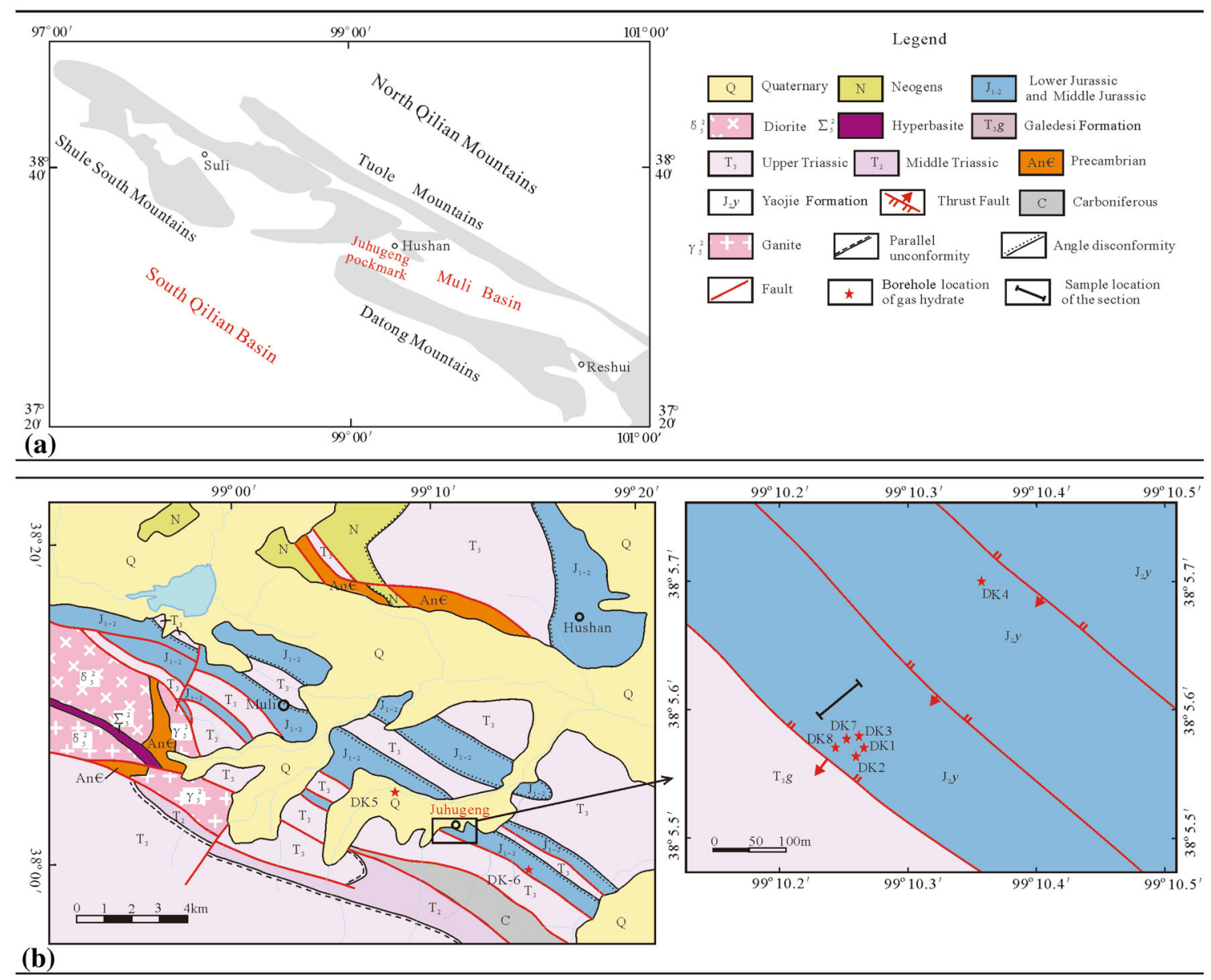

Fig. 1 Location and geological map of the Juhugeng Sag of Muli Basin. a Location of the Juhugeng Sag. b Geological map and wells distribution of gas hydrates in the Juhugeng Sag

layer in the same level or lower parts (Lu et al. 2013), which suggests EOG are closely related to gas hydrates.

\subsection{Samples collecting}

In this study, both shale (including oil shale) and coal samples were collected from Juhugeng Sag of Muli Basin and the sampling locations were carefully selected to cover the coal-bearing stratum (Fig. 2). The shale and coal samples were all from an open-pit mine including 12 samples of shale and 7 coal samples, respectively (Tables 1,2). Shales and coalbed were widely distributed in Juhugeng Sag, the Yaojie Formation developed three to five sets of dark or dark grey organic-rich shale (including oil shale) with thickness ranging from 30 to $40 \mathrm{~m}$. Hydrate samples came from Juhugeng Sag have been characterized extensively in previous studies (Lu et al. 2010; Huang et al. 2016). The gases of hydrates collected in different ways, such as drainage gas collection, mud degasification, vacuum top air method, hydrate decomposition and drilling test mining.
The shale samples were taken from dark shale or oil shale intervals and collected carefully following DB61/T 576-2013 (2014) and the coal samples were obtained following the Chinese Standard Method GB482-1985. Shale samples were cut over an area of $10 \mathrm{~cm}$ wide and $10 \mathrm{~cm}$ deep from situ pillars. In situ coal pillar were removed from the coal seam face and wrapped tightly in aluminium foil to avoid contamination. The distance between each two adjacent coal samples was approximately $2 \mathrm{~m}$. All clay partings thicker than $3 \mathrm{~cm}$ were excluded. Sample numbers together with their depth are shown in Table 2. Each shale sample was split into 4 aliquots that were assessed using vitrinite reflectance analysis, Rock-Eval pyrolysis, TOC content analysis, organic fractions and kerogen and desorbed gas stable carbon isotope $\left(\delta^{13} \mathrm{C}_{\mathrm{PDB}}\right)$. Each coal sample was split into 3 aliquots that were assessed using molecular composition, organic fractions and stable carbon isotope $\left(\delta^{13} \mathrm{C}_{\mathrm{PDB}}\right)$. Stable carbon isotope values and geochemical data of shales were analyzed in the laboratory of Langfang branch of Petro-China Exploration and Development Research Institute. The gas components and 


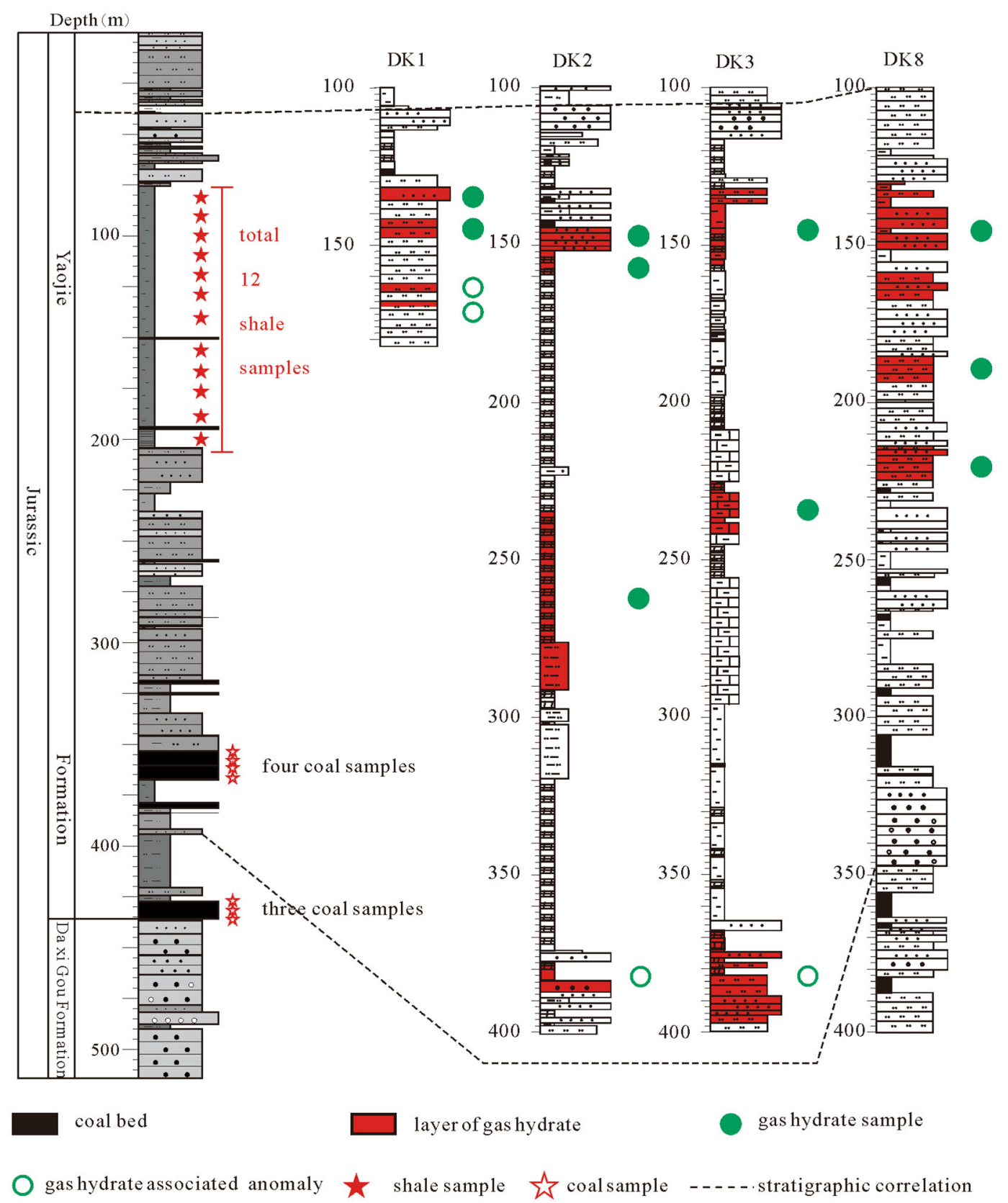

Fig. 2 Stratigraphic column showing the sampling layer and gas hydrates distribution in the Yaojie formation form the Juhugeng Sag (Modified from Tan et al. 2017)

stable carbon isotopes of coal were analyzed in the laboratory of Lanzhou Institute of Geology, Chinese Academy of Sciences.

\subsection{Methodology}

\subsubsection{Organic geochemistry}

The characterization of organics in shales is a critical section in evaluating the hydrocarbon potential of a prospect drilling. For any source rock assessment, the measurement of TOC is a priority and is the first step taken for quantifying organic richness (Hou and Feng 2011). Rock-Eval Pyrolysis is the most commonly used petroleum screening technique (Peters et al. 2005). The shale samples were crushed to 100 mesh sizing and a Rock-Eval 6 instrument was used to detect the pyrolysis parameter, including the remaining hydrocarbon generation potential (S2) as $\mathrm{mg} \mathrm{HC/g}$ rock. More details on this experimental process can be found in Behar et al. (2001).

TOC content was determined using a Leco CS230 carbon/sulfur analyser. The shale samples, weighing about 
Table 1 Sample information, organic geochemical data and isotopic compositions of shale samples

\begin{tabular}{|c|c|c|c|c|c|c|c|c|c|c|c|}
\hline \multirow[t]{2}{*}{ Sample no. } & \multirow[t]{2}{*}{ Sample type } & \multirow[t]{2}{*}{ Rock type } & \multirow[t]{2}{*}{ TOC (\%) } & \multirow[t]{2}{*}{$\mathrm{S}_{2}(\mathrm{mg} / \mathrm{g})$} & \multirow[t]{2}{*}{$R_{\mathrm{O}}(\%)$} & \multirow[t]{2}{*}{ Kerogen $\delta^{13} \mathrm{C}(\%, \mathrm{PDB})$} & \multicolumn{2}{|c|}{$\begin{array}{l}\text { Organic } \\
\text { fractions }\end{array}$} & \multicolumn{3}{|c|}{$\begin{array}{l}\text { Carbon isotope of } \\
\text { desorbed gas }(\%, \mathrm{PDB})\end{array}$} \\
\hline & & & & & & & $\mathrm{H} / \mathrm{C}$ & $\mathrm{O} / \mathrm{C}$ & $\delta^{13} \mathrm{C}_{1}$ & $\delta^{13} \mathrm{C}_{2}$ & $\delta^{13} \mathrm{C}_{3}$ \\
\hline NY01 & Outcrop & Shale & 1.26 & 0.21 & 0.68 & -29.6 & 1.61 & 0.08 & -48.9 & -38.5 & -34.9 \\
\hline NY02 & Outcrop & Shale & 1.34 & 0.34 & 0.82 & -43.5 & 1.73 & 0.09 & -45.6 & -35.4 & -32.6 \\
\hline NY03 & Outcrop & Shale & 1.43 & 0.25 & 0.75 & -37.7 & 1.64 & 0.05 & -46.7 & -36.2 & -33.5 \\
\hline NY04 & Outcrop & Shale & 1.25 & 0.18 & 0.79 & -51.8 & 1.48 & 0.06 & -39.2 & -33.9 & -31.8 \\
\hline NY05 & Outcrop & Shale & 1.77 & 0.65 & 0.63 & -42.3 & 1.66 & 0.08 & -43.6 & -34.1 & -31.9 \\
\hline NY06 & Outcrop & Oil shale & 3.02 & 0.77 & 0.87 & -47.4 & 1.56 & 0.10 & -49.6 & -38.8 & -35.1 \\
\hline NY07 & Outcrop & Oil shale & 2.72 & 0.65 & 0.95 & -46.8 & 1.71 & 0.09 & -48.6 & -38.4 & -34.6 \\
\hline NY08 & Outcrop & Oil shale & 2.45 & 0.45 & 1.32 & -35.3 & 1.58 & 0.06 & -46.2 & -35.8 & -33.4 \\
\hline NY09 & Outcrop & Shale & 1.56 & 0.34 & 0.85 & -39.4 & 1.47 & 0.03 & -43.9 & -34.5 & -32.1 \\
\hline NY10 & Outcrop & Shale & 1.73 & 0.39 & 0.87 & -50.3 & 1.42 & 0.07 & -44.8 & -34.1 & -32.4 \\
\hline NY11 & Outcrop & Oil shale & 3.52 & 0.33 & 0.9 & -45.9 & 1.56 & 0.07 & -47.6 & -36.7 & -33.8 \\
\hline NY12 & Outcrop & Shale & 0.98 & 0.42 & 0.74 & -33.2 & 1.62 & 0.06 & -44.6 & -34.2 & -32.2 \\
\hline
\end{tabular}

Table 2 Sample information, molecular and isotopic compositions of coal samples

\begin{tabular}{|c|c|c|c|c|c|c|c|c|c|c|c|c|}
\hline \multirow[t]{2}{*}{ Sample No. } & \multirow[t]{2}{*}{ Sample type } & \multirow[t]{2}{*}{ Depth (m) } & \multicolumn{5}{|c|}{ Molecular composition (\%) } & \multicolumn{2}{|c|}{$\begin{array}{l}\text { Organic } \\
\text { fractions }\end{array}$} & \multicolumn{2}{|c|}{$\begin{array}{l}\text { Carbon isotope of } \\
\text { desorbed gas }(\% \text {, } \\
\text { PDB) }\end{array}$} & \multirow[t]{2}{*}{ Data sources } \\
\hline & & & $\mathrm{CH}_{4}$ & $\mathrm{C}_{2}-\mathrm{C}_{4}$ & $\mathrm{CO}_{2}$ & $\mathrm{~N}_{2}$ & $\mathrm{C}_{1} / \sum \mathrm{C}_{1}-\mathrm{C}_{4}$ & $\mathrm{H} / \mathrm{C}$ & $\mathrm{O} / \mathrm{C}$ & $\delta^{13} \mathrm{C}_{1}$ & $\delta^{13} \mathrm{C}_{2}$ & \\
\hline $\mathrm{C} 01$ & Outcrop & 356.0 & 17.26 & 0.67 & 12.2 & 70 & 96.26 & 0.58 & 0.16 & -35.1 & -12.9 & This paper \\
\hline $\mathrm{C} 02$ & Outcrop & 357.8 & 15.78 & 0.63 & 6.81 & 77 & 96.16 & 0.73 & 0.14 & -47.2 & -17.5 & \\
\hline $\mathrm{C} 03$ & Outcrop & 369.2 & 17.35 & 0.87 & 5.6 & 76 & 95.23 & 0.66 & 0.13 & -31.7 & -18.2 & \\
\hline $\mathrm{C} 04$ & Outcrop & 361.7 & 35.42 & 0.48 & 7.63 & 56 & 98.66 & 0.78 & 0.17 & -49.6 & -19.6 & \\
\hline $\mathrm{C} 05$ & Outcrop & 427.0 & 17.64 & 0.53 & 5.97 & 76 & 97.08 & 0.72 & 0.12 & -27.9 & -10.8 & \\
\hline $\mathrm{C} 06$ & Outcrop & 429.1 & 15.61 & 0.54 & 9.24 & 75 & 96.66 & 0.64 & 0.14 & -47.3 & -20.8 & \\
\hline $\mathrm{C} 07$ & Outcrop & 430.6 & 34.58 & 1.13 & 18 & 46 & 96.84 & 0.69 & 0.18 & -39.2 & -13.9 & \\
\hline WS-1 & Core & 568.7 & 56.63 & 0.48 & 26.73 & 16.2 & 99.12 & & & -29.5 & -9.5 & Cao et al. (2012) \\
\hline WS-2 & Core & 706.1 & 10.81 & 6.33 & 4.66 & 78.2 & 63.18 & & & -28 & -9.3 & \\
\hline WS-3 & Core & 655.9 & 10.40 & 0.76 & 16.26 & 72.6 & 92.86 & & & -51.4 & -19.3 & \\
\hline WS-4 & Core & 722.4 & 15.27 & 0.42 & 8.05 & 76.3 & 97.45 & & & -30.7 & -18.7 & \\
\hline
\end{tabular}

$1 \mathrm{~g}$, were crushed to a powder with 200 mesh sizing and placed in a porous crucible for $2 \mathrm{~h}$ to remove inorganic carbon within carbonate using $5 \%$ hydrochloric acid at $80{ }^{\circ} \mathrm{C}$. Then the samples were cleaned with distilled water. After the samples were dried at $70{ }^{\circ} \mathrm{C}$ for $12 \mathrm{~h}$, they were reweighed and combusted at higher temperatures. All samples were well homogenized before being used for carrying out experiments. The results of the experiment are shown in Table 1.

Vitrinite reflectance $\left(\% R_{\mathrm{o}}\right)$ values, as indicators for thermal maturity, were determined for 12 samples using an MPV-SP micro-photometer in non-polarized light under oil immersion according to ASTM D 2799-13 (2013), and around 100 measurements were taken for each sample, and the average represented the sample reflectance values.

In addition, to guarantee the accuracy of the kerogen type, kerogen stable carbon isotope $\left(\delta^{13} \mathrm{C}\right)$ levels, which were determined for 12 shale samples using a Delta plus XL instrument, were used to detect the type of organics. Furthermore, it should be noted that the stability of carbon isotopes during thermal maturation (especially for type III) has been of concern. 


\subsubsection{Carbon isotope analysis}

Stable carbon isotope values were analysed in the laboratory of the Langfang branch of Petro-China Exploration and Development Research Institute. Coalbed methane molecular composition and stable carbon isotopes were analysed in the laboratory of the Lanzhou geology institute of the Chinese Academy of Sciences.

Stable carbon isotope values were determined by a Finnigan Mat Delta Plus mass spectrometer interfaced with an HP 5890II chromatograph. Three main procedures were followed: (1) sample preparation (sample combustion-remove oxygen- $\mathrm{CO}_{2}$ transfer-remove other gases), (2) mass spectrometry analysis, and (3) elemental isotope analysis (GBW04407 was selected as the standard material in this study). Stable carbon isotope values were reported using the $\delta$-notation in permil (\%o) relative to V-PDB standard. The measurement precision is estimated to be $\pm 0.5 \%$ for $\delta^{13} \mathrm{C}$.

\subsubsection{Gas composition analysis}

Shale and coal samples were placed into a sealed canister and were taken in a vacuum at 4 to the 5 standard atmospheric pressure. Then, the temperatures were gradually elevated to $90{ }^{\circ} \mathrm{C}$ and kept at that level for $3 \mathrm{~h}$. The chemical compositions of the desorbed gas were determined by an Agilent $6890 \mathrm{~N}$ gas chromatograph (GC) equipped with a flame ionization detector and a thermal conductivity detector. Individual hydrocarbon gas compositions from methane to butane $\left(\mathrm{C}_{1}-\mathrm{C}_{4}\right)$ were separated using a capillary column (PLOT $\mathrm{Al}_{2} \mathrm{O}_{3} 50 \mathrm{~m} \times 0.53 \mathrm{~mm}$ ). Non-hydrocarbon gases were separated using two capillary columns (PLOT Molsieve $5 \AA 30 \mathrm{~m} \times 0.53 \mathrm{~mm}$, PLOT Q $30 \mathrm{~m} \times 0.53 \mathrm{~mm}$ ) (Table 2). The GC oven temperature was initially set at $30{ }^{\circ} \mathrm{C}$ for $10 \mathrm{~min}$ and then increased to $180{ }^{\circ} \mathrm{C}$ at $10^{\circ} \mathrm{C} / \mathrm{min}$ and kept at this temperature for 20-30 min. All the gas compositions have undergone oxygen-free correction and the corresponding correction for nitrogen. Nitrogen was corrected for the presence of traces of oxygen using the area ratio of nitrogen to oxygen peaks measured in the air (Jenden et al. 2015).

\section{Results}

\subsection{TOC content, kerogen type and thermal maturity}

All 12 shale samples contain high TOC content with an average of $1.92 \%$, though exhibiting a variable richness that ranged from $0.98 \%$ to $3.52 \%$ (Table 1 ). These results indicate that these shales may have excellent source potential with TOC values of at least $0.98 \%$ (Tissot et al. 1974; Peters 1986) for all samples. However, TOC content is not necessarily an accurate indicator of hydrocarbon potential for source rock (Harry Dembicki 2009).

Two methods were used to determine kerogen type: (1) kerogen elemental analysis based on $\mathrm{H} / \mathrm{C}$ and $\mathrm{O} / \mathrm{C}$ ratios, (2) carbon stable isotope analysis. All the shale samples composed of Type I kerogen (Fig. 3), which was supported by $\delta^{13} \mathrm{C}_{\mathrm{PDB}}$ values of kerogen ranging between $-29.6 \%$ and - 51.8\%o (Hou and Feng 2011; Table 1).

Measured and calculated $R_{\mathrm{o}}$ values with average of $0.85 \%$ (Table 1) show that almost all shale samples from the Yaojie Formation in the Juhugeng Sag have entered the oil window stage. There is, however, a shale sample with a higher thermal maturity $\left(R_{\mathrm{O}}=1.32 \%\right)$, indicating that some organic matter has entered the condensate gas window phase. Cao et al. (2012) reported the $R_{\mathrm{o}}$ values of coalbed in Muli Basin variation from $0.74 \%$ to $1.85 \%$ with average of $1.19 \%$.

\subsection{Hydrate gas hydrocarbon composition and hydrate structure}

Although the molecular composition of the Juhugeng Sag hydrate gas is mainly methane (36.24\% to $95.29 \%$ ), thermogenic $\mathrm{C}_{2}-\mathrm{C}_{5+}$ hydrocarbons have significant quantities and including non-hydrocarbons such as $\mathrm{N}_{2}$ and $\mathrm{CO}_{2}$ (Table 3). Structure I generally contain small hydrocarbons, methane $\left(\mathrm{C}_{1}\right)$ and ethane $\left(\mathrm{C}_{2}\right)$, and non-

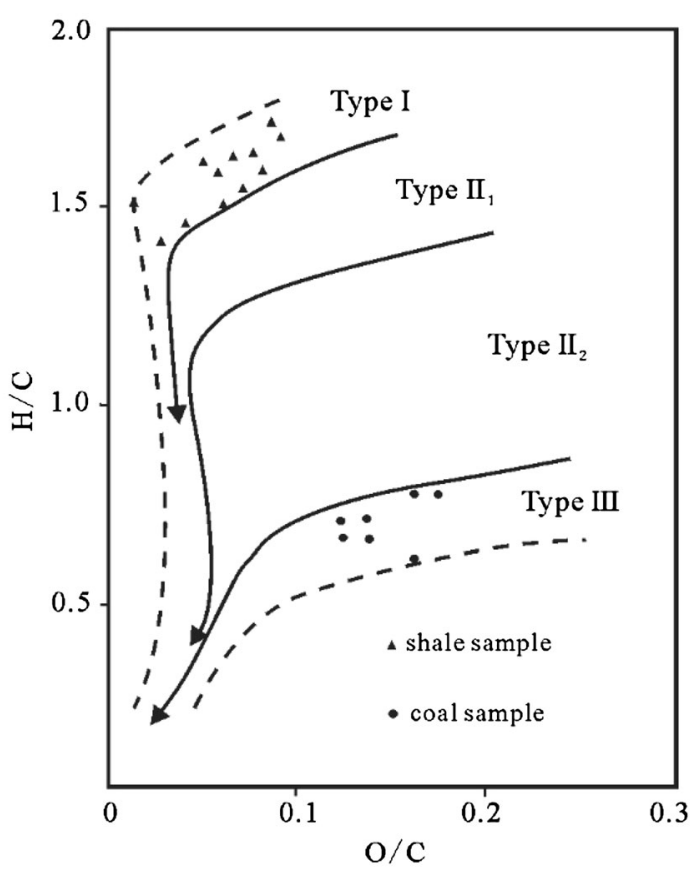

Fig. 3 Van-chart of kerogen plots for the shale and coal samples: $\mathrm{H} / \mathrm{C}$ versus $\mathrm{O} / \mathrm{C}$ 


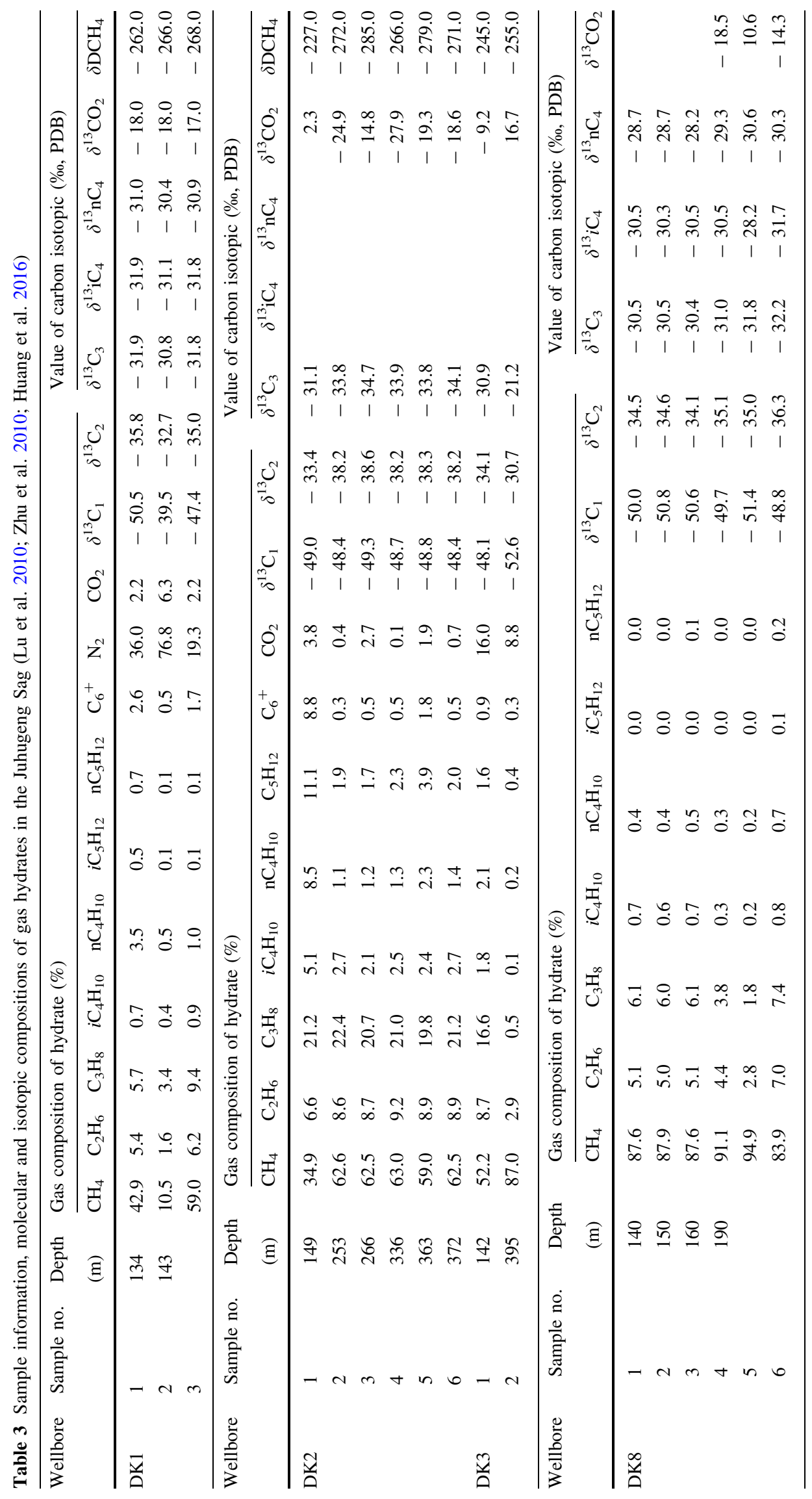


hydrocarbons. In structure II hydrate can contain $\mathrm{C}_{1}$ and $\mathrm{C}_{2}$ in the lattice, and larger molecular can be included such as propane $\left(\mathrm{C}_{3}\right)$ and isobutane $\left(\mathrm{iC}_{4}\right)$ (Brooks et al. 1984). Structure $\mathrm{H}$ hydrate is identified as inclusion of small quantities of larger molecular with diameters exceeding that of $\mathrm{iC}_{4}$ (Sassen and MacDonald 1994). According to the composition of the gases hydrate of Juhugeng Sag, it is similar to structure II hydrates with trace amounts of $\mathrm{sH}$, which is also supported by Zhu et al. (2009).

\subsection{Coalbed methane hydrocarbon composition}

Desorbed gases provide the most realistic indicator of the molecular and isotopic composition of the source rock (Sassen et al. 2004). The coal gases contain methane, ethane, propane and butane. Furthermore, nitrogen and carbon dioxide were detected in the analysis. More than 95.23\% (volume) of coalbed gases is methane with an average of $96.70 \%$ (Table 2), not taking into account the volume of $\mathrm{N}_{2}$ and $\mathrm{CO}_{2}$. The other alkane gases contain only $1.34 \%-4.77 \%$ of the gases.

\subsection{Gases stable isotope composition}

\subsubsection{Shale gas stable carbon-isotope composition}

The isotopic composition of 12 desorbed gases from shale samples in Juhugeng Sag was characterized by the lightest $\delta^{13} \mathrm{C}_{1}$ value, which measured as $-49.6 \%$; the heaviest was $-39.2 \%$, with a main range from $-49.0 \%$ to - 43.0\% (Table 1). While $\delta^{13} \mathrm{C}_{2}$ values mainly ranged from $-39.0 \%$ to $-34.0 \%$ with an average of $-35.9 \%$, and $\delta^{13} \mathrm{C}_{3}$ values distributed primarily between $-31.0 \%$ and $-35.0 \%$ with little variation. The result showed that with the increasing carbon number, the isotope values of hydrocarbon increased gradually.

\subsubsection{Coal gas stable carbon-isotope composition}

The $\delta^{13} \mathrm{C}_{1}$ values of coalbed methane from the Juhugeng Sag range from $-27.9 \%$ o $-51.4 \%$ with an average of - 37.9\%o, including the data was measured by Cao et al. (2012). (Table 2). The $\delta^{13} \mathrm{C}$ of ethane distributes primarily between $-19 \%$ and $-9 \%$. The carbon isotopic values of coal gases were generally heavier than those for gas hydrates. It is noticeable that the carbon isotopic composition between gas hydrates and coalbed methane is quite different.

\subsubsection{Hydrate gas stable isotope composition}

The stable carbon isotope characterises of gas hydrates is commonly used to determine genesis of gases. The $\delta^{13} \mathrm{C}$ of methane ( $-52.6 \%$ to $-39.5 \%$ PDB) varies by $13.1 \%$, however, the values between $-51 \%$ and $-47 \%$ account for above $80 \%$ (Fig. 4). All hydrogen isotopic values from hydrate gases were less than $-190 \%$, indicating that the source rock is a terrestrial environment (Fig. 5). The $\delta^{13} \mathrm{C}_{2}$ values range from $-38.6 \%$ to $-30.7 \%$ while $\delta^{13} \mathrm{C}_{3}$ values showed heavier than $\delta^{13} \mathrm{C}$ of ethane (Table 3). The $\delta^{13} \mathrm{C}$ of $\mathrm{CO}_{2}$ from gas hydrates range from $-27.9 \%$ to $16.7 \%$ and distribute mostly between $-20 \%$ and $-17 \%$ (Fig. 4, Table 3). In a word, carbon isotopic compositions of the gas hydrates are characterized by the positive carbon isotopic sequence (i.e., $\delta^{13} \mathrm{C}_{1}<\delta^{13} \mathrm{C}_{2}<\delta^{13} \mathrm{C}_{3}$ ) (Table 3). This result demonstrates that the alkane gas was of organic origin and without strong secondary reconstructing (Milkov 2005).

\section{Discussion}

\subsection{Origin of the hydrate bound gas}

It is widely acknowledged that gas hydrates primarily consist of alkane gas, therefore, in this study, we focus on the origin of alkane gas. It was obtained from previous studies that with gas genesis, correlation, migration and accumulation, as well as hydrocarbon source rocks with reservoir evaluation and coal gas, shale gas and tight sandstone gas, desorbed gas is an important element of the geochemistry of hydrocarbon (Zumberge et al. 2012). Based on source rocks in the Turpan-Hami, Santanghu and Liaohe Basins, the research around desorbed gas geochemical characteristics indicated that the desorbed gas shares similar geochemical characteristics with source rock (Starostin et al. 2008; Liu et al. 2016a, b). A comprehensive analysis was carried out on the geochemical characteristics of 17 gas hydrate samples from four scientific drillings in Juhugeng Sag (Table 3), comparing with the experiment results of the 12 shale samples and 7 coal samples from this study (Tables 1,2 ). The $\mathrm{C}_{1} / \sum \mathrm{C}_{1}-\mathrm{C}_{4}$ of coal gases primarily ranged between $92.86 \%$ and $99.12 \%$ with only two samples lower than $95 \%$, however, $\mathrm{C}_{1} /$ $\sum \mathrm{C}_{1}-\mathrm{C}_{5}$ of gas hydrates mainly ranged from $61.27 \%$ to $95.57 \%$. The alkane gas of coalbed methane is smaller than that for gas hydrates. The methane content of coalbed methane is higher than that for hydrate samples, however, the $\mathrm{C}_{2+}$ content of coalbed gases far lower than that for gas hydrates. In a word, alkane gases composition between coalbed methane and gas hydrates display great differences. Sloan (1998) considered that the change in phase from free gas to solid structure II gas hydrate involves molecular fractionation favouring gases of appropriate molecular diameter, in generally, methane decreases in 

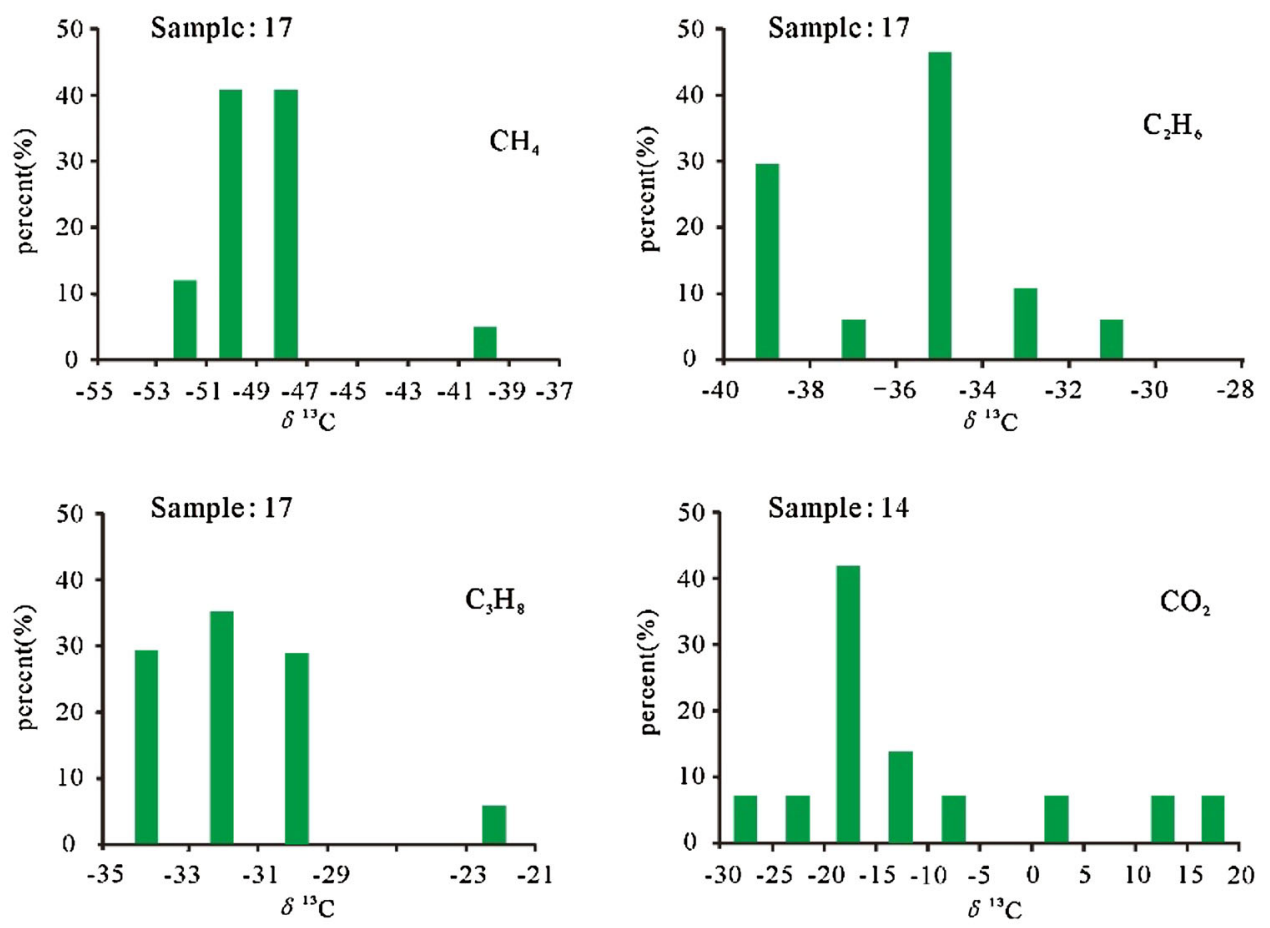

Fig. 4 Graph showing a carbon isotopic frequency comparison of alkane gases and carbon dioxide of gas hydrates

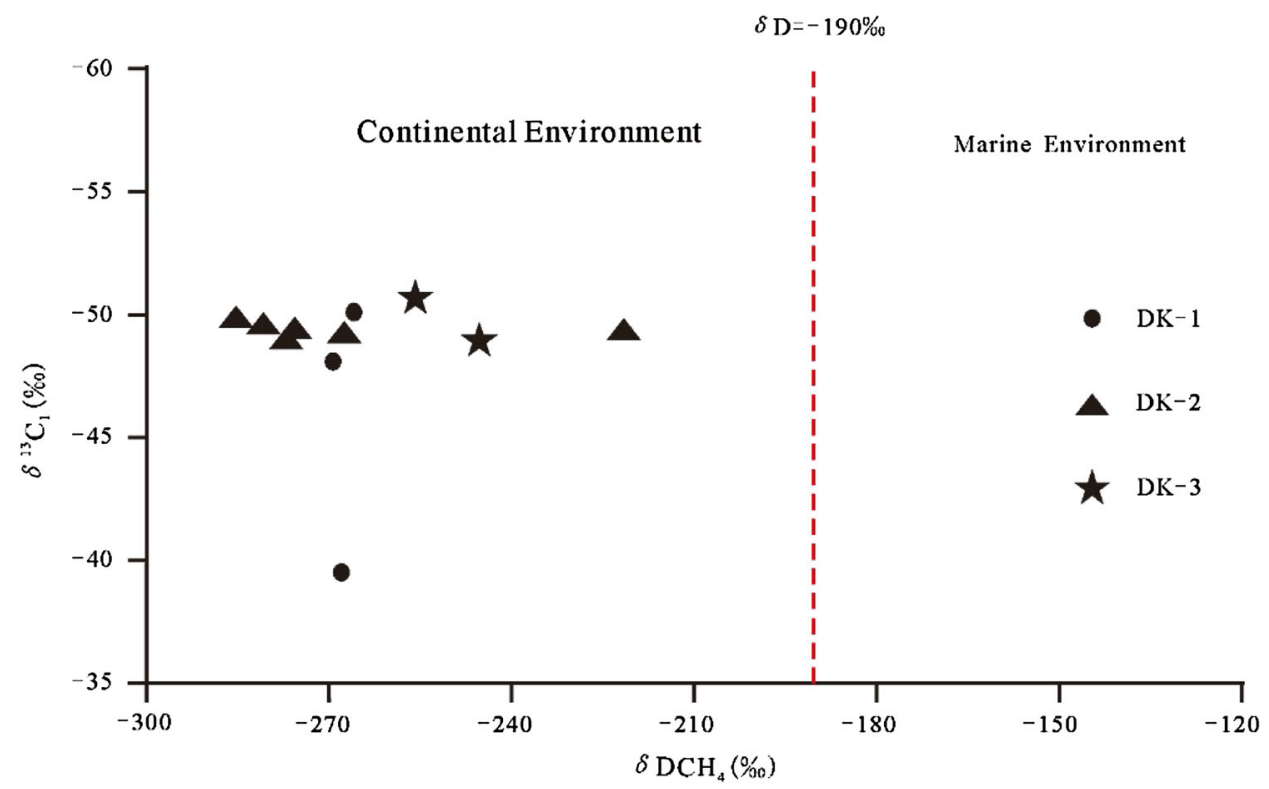

Fig. 5 Diagram of the $\delta^{13} \mathrm{C}$ versus $\delta \mathrm{D}$ indicating the gaseous source environment of gas hydrates (after Dai and Li 1995)

abundance relative to free gas, and $\mathrm{C}_{2}-\mathrm{C}_{4}$ hydrate bound gases increase in abundance.

The range and distribution of the stable carbon isotope characteristics of the hydrocarbon gases are a function of the origin and maturity of the source rock (James 1983; Whiticar 1996) as well as post-generational alterations, for example, source mixing (Chung et al. 1988), accumulation history (Whiticar 1996) and biodegradation (Chung et al. 1988; Katz et al. 2002). As gas hydrate crystallization does not cause significant isotopic fractionation (Table 3, Brooks et al. 1986; Sassen and MacDonald 1997), the isotopic information recorded in gas hydrates (Table 3) may be available for identifying hydrate gas-source rock correlations. Carbon isotopic compositions of hydrocarbon 
from gas hydrates are heavier with an increasing carbon number (i.e., $\delta^{13} \mathrm{C}_{1}<\delta^{13} \mathrm{C}_{2}<\delta^{13} \mathrm{C}_{3}$ ) as well as the carbon isotopic compositions of shale gas. This result indicates that the alkane gases from gas hydrates were of organic origin and the carbon isotopic compositions between gas hydrates and shale gas show a similar consistency (Tables 1, 3). Compositional similarities suggest gases from hydrates are derived from the free hydrocarbon gases of sediments. In addition, as shown in Fig. 6, most of carbon dioxide from gas hydrates were of organic origin except two samples, mixture and inorganic origin, respectively. In contrast, previous studies showed that the structure II and structure $\mathrm{H}$ hydrates from the Gulf of Mexico contain $\delta^{13} \mathrm{C}$ of $\mathrm{CO}_{2}$ ranging from $-4.4 \%$ to $18.5 \%$, and is thermogenic origin from vent gas (Brooks et al. 1984; Sassen and MacDonald 1994). It may explain the origin of $\mathrm{CO}_{2}$ from gas hydrate.

The stable carbon isotope signature of methane from gas hydrates is generally used to interpret the methane origin (microbial or thermogenic source). Pure microbial methane typically has $\delta^{13} \mathrm{C}$ values less than $-55 \%$, and pure thermogenic methane has $\delta^{13} \mathrm{C}$ values heavier than $-55 \%$ (Jarvie et al. 2007; Dai 2011). The mixtures of microbial and thermogenic methane have broad range of values depending on the relative contributions and $\delta^{13} \mathrm{C}$ values of the microbial and thermogenic end members. In addition, some other factors may effect on $\delta^{13} \mathrm{C}$ values of methane such as microbial methane oxidation (Whiticar 1999) and methanogenesis (Claypool et al. 1985). Furthermore, the carbon isotope of $\mathrm{C}_{2+}$ hydrocarbons is available for

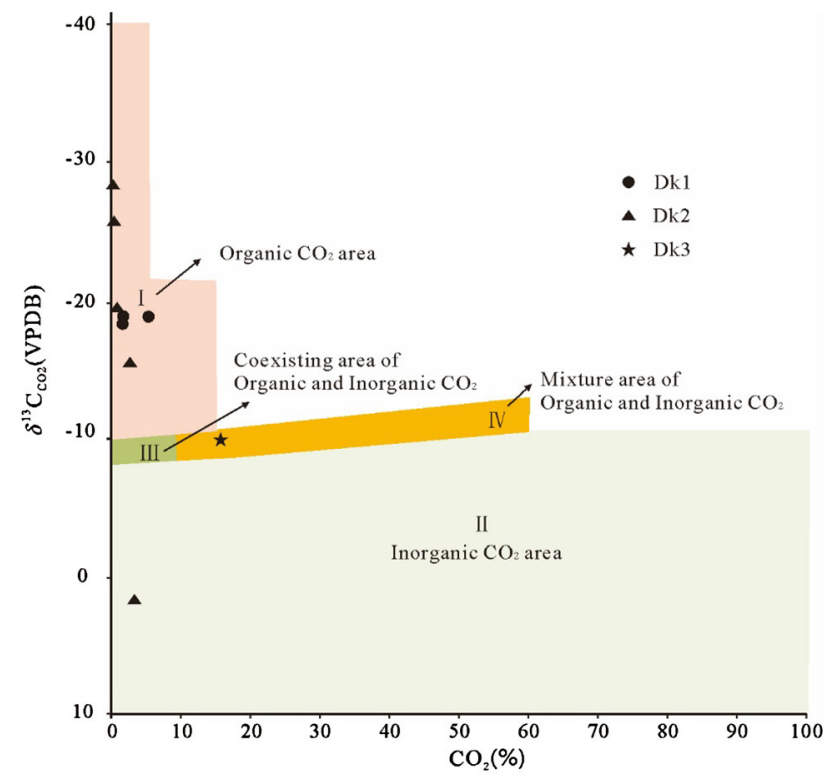

Fig. 6 Genetic types of carbon dioxide from gas hydrates in the Juhugeng Sag (after Dai and Li 1995) distinguishing source effects from mixing and microbial alteration (Katz et al. 2002; Sassen et al. 2003).

The alkane of gas hydrates from Juhugeng Sag corresponds to a thermogenic gas because all of the $\delta^{13} \mathrm{C}_{1}$ values are heavier than $-55 \%$ (Table 3 , Fig. 7). Based on the types of source rocks, thermogenic gases can be divided into two types, an oil-prone gas (sapropel type gas) and a coal type gas (humus type gas). Previous studies have shown that the thermal maturity of source rocks holds more influence on methane carbon isotopic values than that on ethane (Zhang et al. 1988; Milkov 2005). Therefore, it is common to use the carbon isotopic composition of ethane to identify that the alkanes of gas hydrates are oil-prone gas or coal type gas.

As shown in Fig. 7, in most gas hydrate, the methane has molecular and isotopic characteristics that can be inferred to thermogenic origin. The hydrate gas contains a larger percentage $(7.1 \%$ and $13 \%$ ) of ethane and propane in total hydrocarbons of Juhugeng Sag (Table 3), which is corresponds with the type of hydrate gas as structure II hydrate. Since ethane and propane were typically combined in hydrate structure compared to ethane and propane concentrations in the surroundings, they could also cause the value of $\mathrm{C}_{1} /\left(\mathrm{C}_{2}+\mathrm{C}_{3}\right)$ ratio become lower (Milkov et al. 2005). In this case, the value of $C_{1} /\left(C_{2}+C_{3}\right)$ ratio is consistent with the light carbon isotope values of ethane and propene of hydrate gas.

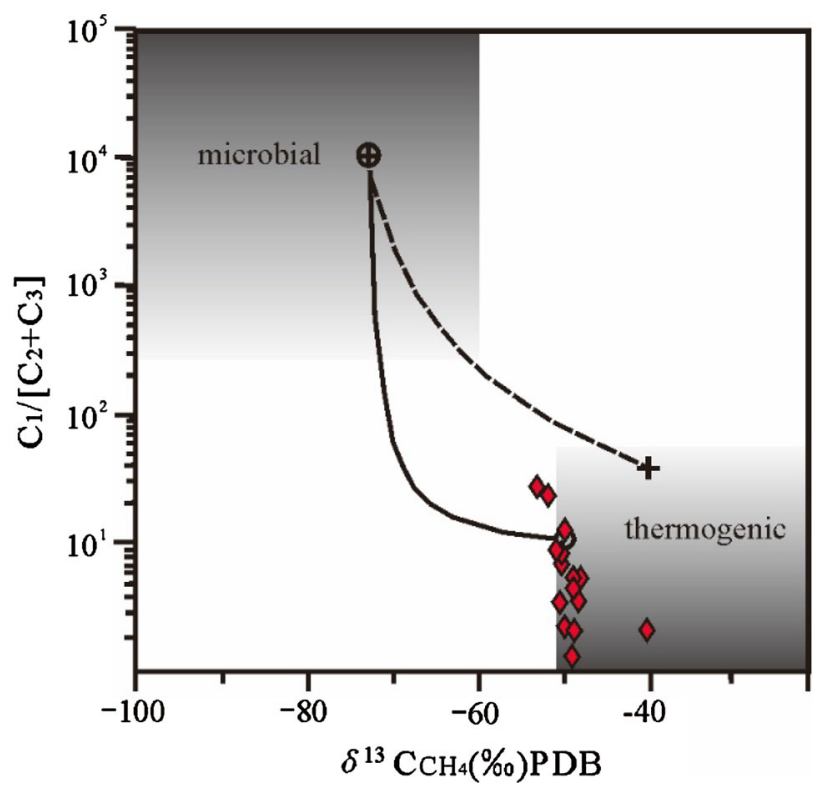

Fig. 7 Volumetric hydrocarbon gas ratio of $\mathrm{C}_{1} /\left(\mathrm{C}_{2}+\mathrm{C}_{3}\right)$ versus $\delta^{13} \mathrm{C}$ of methane to show the methane formation zones. Modelled from Bernard et al. (1978), two suggested mixing lines are indicated between microbial field and thermal sources field; both lines start from the end-member microbial gas $(-73 \% ; 104)$ and end with thermogenic gas end-member $(-50 \% ; 10)$ and $(-40 \%$; 50$)$, respectively 
Characteristics of stable carbon isotopes are used to determine the origin of gases, which have recently become significantly successful in worldwide basins (Pohlman et al. 2005; Vaular et al. 2010). However, the $\delta^{13} \mathrm{C}$ signature of ethane is a determining criterion that remains controversial (i.e., $\delta^{13} \mathrm{C}_{2}<-28.5 \%$ or $\delta^{13} \mathrm{C}_{2}<-29 \%$ ). Zhang et al. (1988) found that ${ }^{13} \mathrm{C}_{2}$ of ethane from coal type gas often was heavier than $-29 \%$, and that from oil prone gas was less than $-29 \%$. However, he didn't consider a gap for mixing gas between coal type gas and oil type gas. Dai (2011) compared hundreds samples of natural gases in southwest of China with Texas Barnett and all of them are similar to unaltered hydrocarbon gases (i.e., $\delta^{13-}$ $\mathrm{C}_{1}<\delta^{13} \mathrm{C}_{2}<\delta^{13} \mathrm{C}_{3}<\delta^{13} \mathrm{C}_{4}$ ), and suggested the $\delta^{13} \mathrm{C}_{2}$ values of coal-type gases are mostly greater than $-28 \%$, while those of oil-type gas are commonly less than $-28.5 \%$, and both types of gas might occur in the interval between $-28 \%$ and $-28.5 \%$ with predominant coal type gases. In the study, all the $\delta^{13} \mathrm{C}_{2}$ of gas hydrates are less than $-28.5 \%$ o (Table 3 ). We can conclude that the gases of gas hydrates from the Juhugeng Sag in the Muli Basin are similar to the oil type gas, which is also supported by almost all the samples of gas hydrates distributed in the oil-type area (Fig. 8).

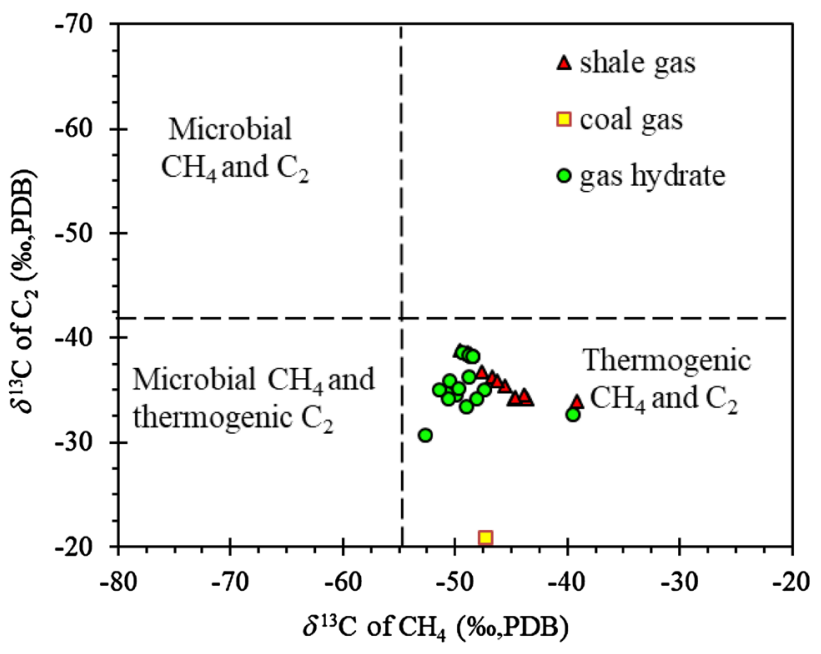

Fig. 9 The $\delta^{13} \mathrm{C}$ of methane versus $\delta^{13} \mathrm{C}$ of ethane of gas hydrate from Milkov plot. Our data plot in the thermogenic methane and ethane areas. Modified from Milkov (2005) and Bernard et al. (1978)

In Fig. 9, all samples including shale gas and coalbed methane and gas hydrate were plotted in the thermogenic methane and ethane field, however, only one coalbed methane sample was presented as most of $\delta^{13} \mathrm{C}$ of ethane of coalbed methane were heavier than $-20 \%$. The carbon

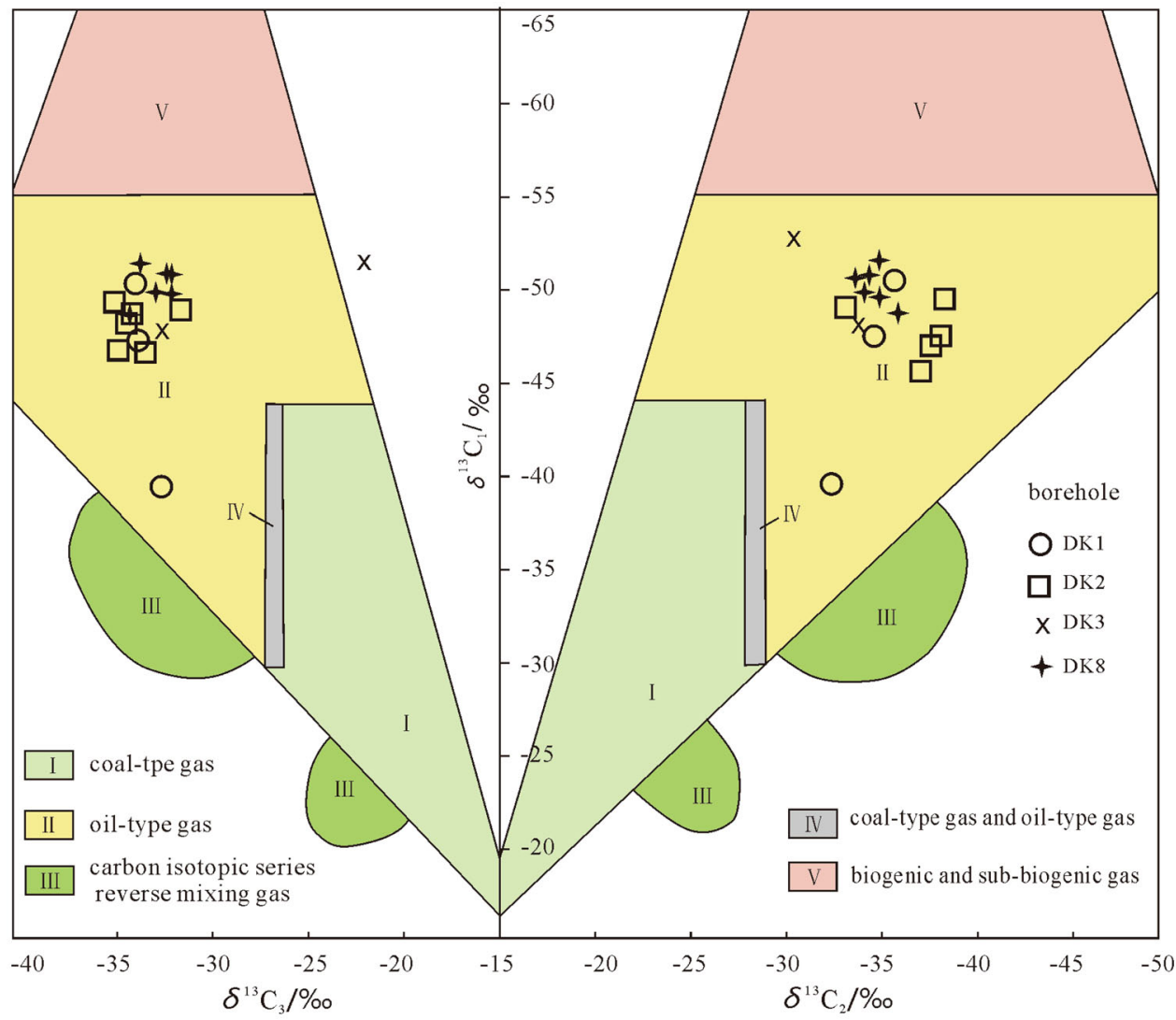

Fig. 8 Plot of $\delta^{13} \mathrm{C}_{1}$ vs $\delta^{13} \mathrm{C}_{2}$ and $\delta^{13} \mathrm{C}_{3}$ of hydrocarbon gases from gas hydrates in the Juhugeng Sag (after Dai 1993) 
isotope values of the methane and ethane plots indicate that both methane and ethane from all samples are thermogenic gas.

\subsection{Implications of the isotope data from gas hydrates and source rock}

In this study, we have carried out a carbon isotopic composition and hydrocarbon component analysis and comparison. The comparison of the carbon isotopic composition of gases between hydrate gas and shale gas shows that they have a high consistency. The carbon isotopes of both gas hydrate gas and shale gas mainly range from $-30 \%$ to $-50 \%$ and have a positive carbon isotopic sequence. All the $\delta^{13} \mathrm{C}_{2}$ values are less than $-28.5 \%$, indicating that alkane gases of gas hydrates from the Juhugeng Sag in the Muli Basin correspond to an oil type gas and came from source rocks of the Yaojie Formation. However, some researchers in China have believed that the gases of gas hydrates originated from the Upper Triassic (Lu et al. 2010, 2013; Huang et al. 2016).

The shale from the Upper Triassic is characterized by TOC values ranging from $0.11 \%$ to $7.75 \%$ with an average of $1.21 \%$. The $R_{\mathrm{o}}$ is at $1.37 \%$, and it is characterized as kerogen type I and type II with having a good hydrocarbon generating potential in previous studies (Lu et al. 2013). If the gas hydrate is to be identified as autochthonous, the migration distance may be short and should source from the gas hydrate stability zone (GHSZ). However, if the gases migrated upward from the Upper Triassic by gas diffusion, it should go through the coal seam of Jurassic. The coal methane would be mixed up with the oil type gas, and then the carbon isotopic composition of the alkane gases would exhibit partial reversal or even a complete reversal. In fact, the hydrate bound gases present a positive sequence. Obviously, the gas hydrates distribution in Juhugeng Sag is controlled by faults system and stratigraphic hydrate reservoirs. While the gases from Upper Triassic or deeper source rock migrated mainly vertically through faults which were the main migration channels without mixed with coalbed gases, the structure II gas hydrate is assumed to have crystallized from the associated gas pool (Fig. 10a). Because of the similarity between hydrate gas and shale gas with stable carbon isotope compositions of hydrocarbon, hydrate could also be crystallized from free hydrocarbon gases of Jurassic sediments (Fig. 10b). Two schematic drawings in Fig. 10a and b illustrates the fluid flow forming model, the forming model of source gases of hydrate may be more complicated and need further understanding.

Autochthonous gases and allochthonous gases are two potential sources of gases in gas hydrates. Autochthonous gases originate from organic matter dispersed mainly

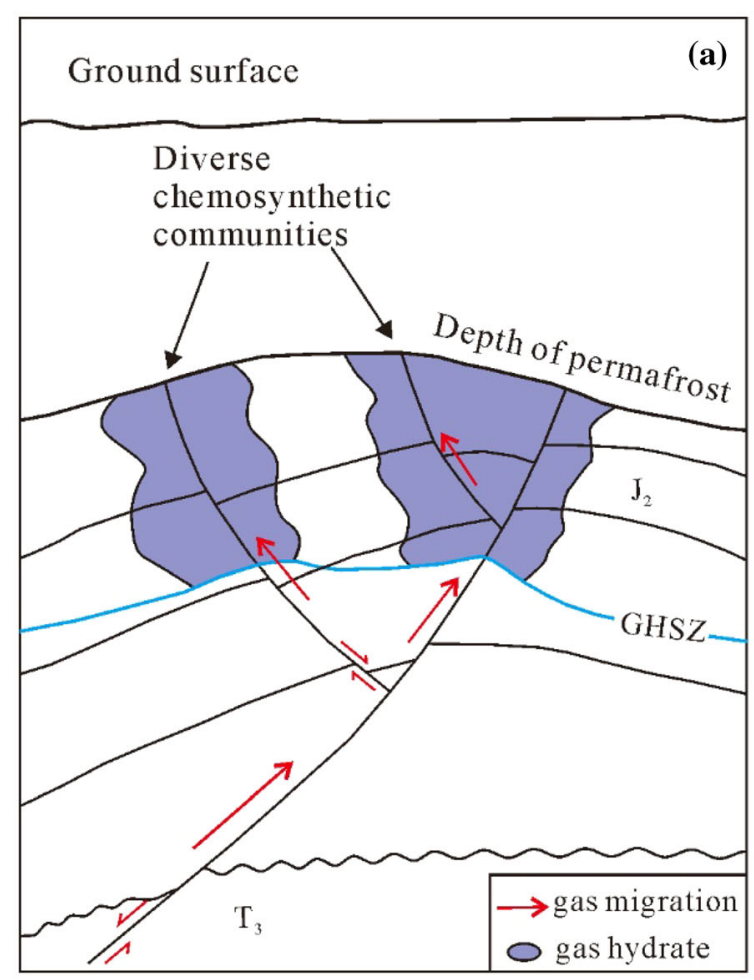

Ground surface

(b)

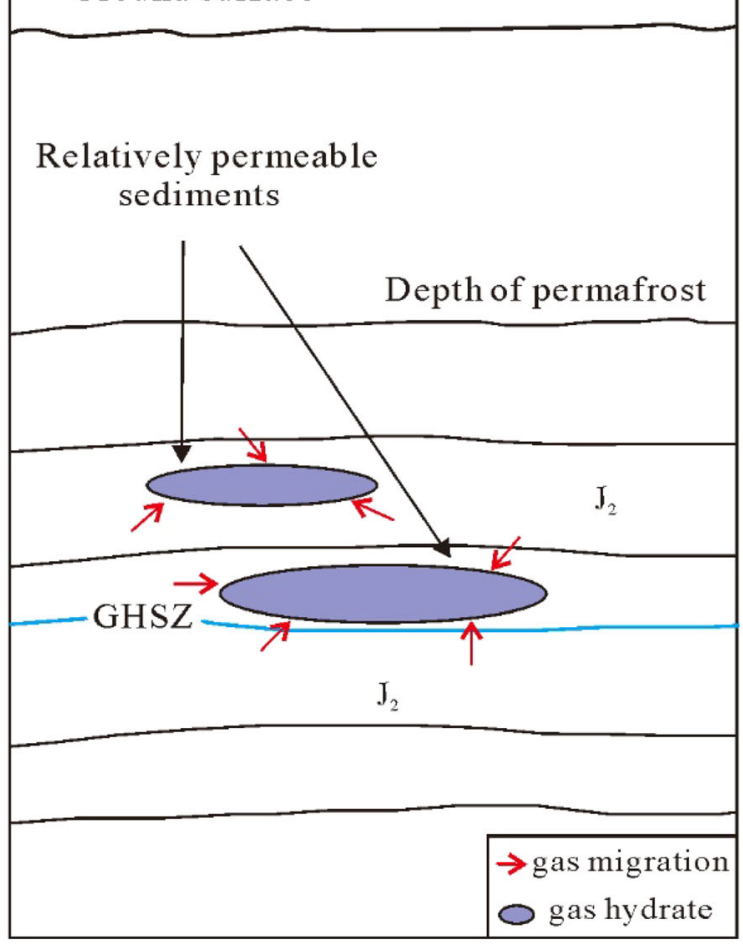

Fig. 10 Gas hydrate forming associated with a a fault system; b stratigraphy

throughout the GHSZ, and migrate short distances to sites of hydrate crystallization. In a dynamic gas hydrate system, the migration processes between the gases from 
decomposition of gas hydrates and the free gas pool are interactive (Paull et al. 1994; Tang et al. 2007; Li et al. 2012). In contrast, allochthonous gases generate much greater depth below the GHSZ, migrating long distances from deep petroleum system along faults or other channel (Sassen and MacDonald 1994; Milkov et al. 2005; Wang et al. 2016). In summary, it suggests that the sources of gases in gas hydrate are primarily thermogenic hydrocarbon migrated into the GHSZ, which could derive from source rock of the Yaojie Formation or deeper gas migration basing on the reasons as following: (1) the shales of the Yaojie Formation have excellent TOC content $(>1.92 \%)$, moderate thermal maturity $\left(>0.85 \% \mathrm{R}_{\mathrm{o}}\right)$, kerogen type I, and large thicknesses of shale intervals $(>30 \mathrm{~m})$. These findings indicate a great quality of source rock hydrocarbon generating potential, (2) The $\delta^{13} \mathrm{C}$ of hydrocarbons from source rocks in the Yaojie Formation and gas hydrates have high consistency, showing a certain affinity, (3) there have great differences between the $\delta^{13} \mathrm{C}$ of hydrocarbons and gas components of coalbed gases in the Yaojie Formation and gas hydrates, (4) Carbon isotopic compositions of hydrocarbon from hydrate bound gases are characterized by the primary positive sequence (i.e., $\delta^{13-}$ $\mathrm{C}_{1}<\delta^{13} \mathrm{C}_{2}<\delta^{13} \mathrm{C}_{3}$ ) and thermogenic gas, (5) the shales of Upper Triassic have a good hydrocarbon generating potential, and (6) the gas hydrates distribution in Juhugeng Sag is controlled by faults system and stratigraphic hydrate reservoirs.

\section{Conclusions}

The gas hydrates have been successfully recovered from the Yaojie Formation in Juhugeng Sag recently. Stable isotope $\left({ }^{13} \mathrm{C}\right.$ and D) and relative hydrocarbon abundance data from hydrate gas compare with shale gas and coal bed methane as well as the geochemistry analysis, which leads to following conclusions:

(1) The shale of the Middle Jurassic Yaojie Formation in the Juhugeng Sag of the Muli Basin is characterized by high TOC values $(0.98 \%-3.52 \%)$ of type I organics and of average $R_{\mathrm{o}}$ values $(0.63 \%-1.32 \%)$. This result indicates that the shales have a good hydrocarbon generating potential.

(2) Carbon isotopic compositions of hydrate bound gases are characterized by the positive sequence (i.e., $\delta^{13} \mathrm{C}_{1}<\delta^{13} \mathrm{C}_{2}<\delta^{13} \mathrm{C}_{3}$ ) and without a $\delta^{13} \mathrm{C}_{2}$ heavier than $-28.5 \%$. The $\delta^{13} \mathrm{C}$ of methane from hydrate gas is totally heavier than $-55 \%$. The hydrocarbon from gas hydrates have $\mathrm{C}_{1} / \Sigma \mathrm{C}_{2+}$ values mainly ranging from 0.57 to 20.22 . Therefore we conclude that the hydrocarbon gases in the hydrate are thermogenic source as well as the representative of oil-prone gas and unaltered gas.

(3) The carbon isotopic compositions of the alkane gases from the source rock in the Yaojie Formation and the gas hydrates show highly consistency.

(4) Two potential end member sources of gases in gas hydrates are free gas from the Yaojie Formation and gas from deeper mature source rock via fault system, respectively.

Acknowledgements This study was supported by the National Natural Science Fundamental of China (No. 41702144), the Fundamental Research Funds for the Central Universities (No. 2652018234) and the Key Program of exploration Foundation of Qinghai province (No. 2017042007ky007). The authors wish to thank Prof. Yuzhuang Sun for his comments and suggestions to improve the manuscripts.

Open Access This article is distributed under the terms of the Creative Commons Attribution 4.0 International License (http://crea tivecommons.org/licenses/by/4.0/), which permits unrestricted use, distribution, and reproduction in any medium, provided you give appropriate credit to the original author(s) and the source, provide a link to the Creative Commons license, and indicate if changes were made.

\section{References}

Behar F, Beaumont V, De B, Penteado HL (2001) Rock-Eval 6 technology: performances and developments. Oil Gas Sci Technol Rev IFP 56:111-134

Brooks JM, Kennicutt MC, Fay RR, McDonald TJ, Sassen R (1984) Thermogenic gas hydrates in the Gulf of Mexico. Science 225:409-411

Brooks JM, Cox HB, Bryant WR, Kennicutt MC II, Mann RG, McDonald TJ (1986) Association of gas hydrates and oil seepage in the Gulf of Mexico. Org Geochem 10:221-234

Buffett BA (2000) Clathrate hydrates. Annual review of earth and planetary. Sciences 28:477-507

Cao DY, Liu TJ, Wang D, Wang T, Wen HJ, Pan YL (2009) Analysis of formation conditions of natural gas hydrate in Muli coalfield, Qinghai Province. Coal Geol China 21(9):3-6

Cao DY, Wang D, Li J, Dou XQ (2012) Gas source analysis of natural gas hydrate of Muli coalfield in Qilian Mountain permafrost, Qinghai Province, China. J China Coal Soc 37(8):1364-1368

Cheng QS, Gong JM, Zhang M, Wang WC, Chen WJ, Jiang YB, Xu CF, Chen ZQ, Tian RC (2016) Geochemical characteristics of hydrocarbon source rocks in the Qilian Mountain permafrost and gas sources for gas hydrate. Mar Geol Quat Geol 36(5):2281-2282

Chung HM, Gormly JR, Squires RM (1988) Origin of gaseous hydrocarbons in subsurface environments-theoretical considerations of carbon isotope distribution. Chem Geol 71:97-103

Claypool GE, Threlkeld CN, Mankiewicz PN, Arthur MA, Anderson TF (1985) Isotopic composition of interstitial fluids and origin of methane in slope sediment of the Middle America Trench, deepsea drilling project Leg-84. Initial Rep Deep-Sea Drill Proj 84:683-691

Collett TS, Johnson AH, Knapp CC, Boswell R (2009) Natural gas hydrates-energy resource potential and associated geologic hazards. AAPG Memoir 89:146-219 
Collett T, Lee MW, Agena WF, Miller JJ, Lewis KA, Zyrianova MV, Boswell R, Inks TL (2011) Permafrost-associated natural gas hydrate occurrences on the Alaska North Slope. Mar Pet Geol 28:279-294

Dai JX (1993) Hydrocarbon isotopic characteristics of natural gas and the identification of various types of natural gas. Nat Gas Geosci $4(2-3): 1-40$

Dai JX (2011) Significance of the study on carbon isotopes of alkane gases. Nat Gas Ind 31(12):1-6

Dai JX, Li PJ (1995) A study on carbon isotopes of $\mathrm{C}_{5-8}$ light hydrocarbon monomeric series of natural gas in main oil and gas bearing basins in china. Chin Sci Bull 40(6):497

Dai JX, Ni YY, Huang SP, Peng WL, Han WX, Gong DY, Wei W (2017) Genetic types of gas hydrates in china. Pet Explor Dev 44(6):887-898

Dallimore SR, Collett TS (1995) Intra permafrost gas hydrates from a deep core-hole in the Mackenzie Delta, Northwest Territories, Canada. Geology 23:527-530

Harry Dembicki Jr (2009) Three common source rock evaluation errors made by geologists during prospect or play appraisals. AAPG Bull 93(3):341-356

Hou DJ, Feng ZH (2011) Oil and gas geochemistry. Petroleum Industry Press, Beijing, p 200

Huang RH (1996) Geotectonic evolution and characteristics in Qilian Mountains. Geotectonica et Metallogenia 20:95-104

Huang X, Liu H, Zhang JZ, Wang PK, Xiao R, Pang SJ, Zhang S, Zhu YH (2016) Genetic-type and its significance of hydrocarbon gases from permafrost-associated gas hydrate in Qilian Mountian. Chin J Geol 51(3):934-945

James AT (1983) Correlation of natural-gas by use of carbon isotopic distribution between hydrocarbon components. AAPG Bull 67:1176-1191

Jarvie DM, Hill RJ, Ruble TE, Pollastro RM (2007) Unconventional shale-gas systems: the Mississippian Barnett Shale of northcentral Texas as one model for thermogenic shale-gas assessment. AAPG Bull 91:475-499

Jenden PD, Titley PA, Worden RH (2015) Enrichment of nitrogen and ${ }^{13} \mathrm{C}$ of methane in natural gases from the Khuff Formation, Saudi Arabia, caused by thermochemical sulfate reduction. Org Geochem 82:54-68

Katz BJ, Narimanov A, Huseinzadeh R (2002) Significance of microbial processes in gases of the South Caspian Basin. Mar Pet Geol 19:783-796

Li XS, Yang B, Zhang Y, Li G, Duan LP, Wang Y, Chen ZY, Huang NS, Wu HJ (2012) Experimental investigation into gas production from methane hydrate in sediment by depressurization in a novel pilot-scale hydrate simulator. Appl Energy 93:722-732

Li XS, Xu CG, Zhang Y, Ruan XK, Li G, Wang Y (2016) Investigation into gas production from natural gas hydrate: a review. Appl Energy 172:286-322

Liu SQ, Jiang ZX, Liu H, Pang SJ, Xia ZY, Jin ZH, Wang JH, Wei XJ (2016a) The natural-gas hydrate exploration prospects of the Nayixiong Formation in the Kaixinling-Wuli Permafrost, Qinghai-Tibet Plateau. Mar Pet Geol 72:179-192

Liu Y, Zhang JC, Tang X (2016b) Predicting the proportion of free and adsorbed gas by isotopic geochemical data: a case study from lower Permian shale in the southern North China basin (SNCB). Int J Coal Geol 156:25-35

Lu ZQ, Zhu YH, Zhang YQ, Wen HJ, Li YH, Xia ZY, Wang KP, Li QH (2010) Study on genesis of gases from gas hydrate in the Qilian Mountain permafrost, Qinghai. Geoscience 24(3):581-588

Lu ZQ, Zhu YH, Zhang YQ, Liu H, Wang T (2013) Gas source conditions for gas hydrate in Qilian Mountain permafrost of Qinghai and their implications. Min Depos 32(5):1035-1044
Milkov AV (2005) Molecular and stable isotope compositions of natural gas hydrates: a revised global dataset and basic interpretation in the context of geological settings. Org Geochem 36:681-702

Milkov AV, Claypool GE, Lee Y-J, Sassen R (2005) Gas hydrate systems at Hydrate Ridge offshore Oregon inferred from molecular and isotopic properties of hydrate-bound gases. Geochim Cosmochim Acta 39:1007-1026

Nandanwar MS, Anderson BJ, Ajayi T, Collett TS, Zyrianova MV (2016) Evaluation of gas production potential from gas hydrate deposits in National Petroleum Reserve Alaska using numerical simulations. J Nat Gas Sci Eng 36:760-772

Paull CK, Ussler W III, Borowski WS (1994) Sources of biogenic methane to form marine gas hydrates: in situ production or upward migration? Ann New York Acad Sci 715:392-409

Peters K (1986) Guidelines for evaluating petroleum source rock using programmed pyrolysis. AAPG Bull 70:318-329

Peters KE, Walters CC, Moldowan JM (2005) The biomarker guide Biomarkers and isotopes in the environment and human history, vol 1. Cambridge University Press, New York

Pohlman JW, Canuel EA, Chapman NR, Spence GD, Whiticar MJ, Coffin RB (2005) The origin of thermogenic gas hydrates on the northern Cascadia Margin as inferred from isotopic $\left({ }^{13} \mathrm{C} /{ }^{12} \mathrm{C}\right.$ and $\mathrm{D} / \mathrm{H})$ and molecular composition of hydrate and vent gas. Org Geochem 36:703-716

Sassen R, MacDonald IR (1994) Evidence of structure-H hydrate, Gulf of Mexico continental slope. Org Geochem 22:1029-1032

Sassen R, MacDonald IR (1997) Hydrocarbons of experimental and natural gas hydrates, Gulf of Mexico continental slope. Org Geochem 26:289-293

Sassen R, Sweet ST, Milkov AV, DeFreitas DA, Kennicutt MC II (2003) Thermogenic vent gas and gas hydrate in the Gulf of Mexico slope: is gas hydrate decomposition significant. Geology 29:107-110

Sassen R, Roberts HH, Carney R, Milkov AV, DeFreitas DA, Lanoil B, Zhang CL (2004) Free hydrocarbon gas, gas hydrate, and authigenic minerals in chemosynthetic communities of the northern Gulf of Mexico continental slope: relation to microbial processes. Chem Geol 205:195-217

Sloan ED (1998) Clathrate hydrates of natural gases. Marcel Dekker, New York

Sloan ED, Koh CA (2008) Clathrate hydrates of natural gases, 3rd edn. CRC Press, New York

Starostin VI, Kondrayov LS, Voinkov DM (2008) Gas field of the lithosphere and possibilities of the use of adsorbed gases in rocks in prospecting for mineral resources. Earth Sci Front 15(1):51-56

Sun YG, Chen ZX, Liu YA, Wang TQ (2000) Junction and evolution of the Qinling, Qilian and Kunlun orogenic belts. Acta Geol Sin 74(2):223-228

Tan FR, Liu SM, Cui WX, Wan YQ, Yang C, Zhang GC, Liu WG, Du FP, Fan YH (2017) Origin of Gas Hydrate in the Juhugeng Mining area of Muli Coalfield. Acta Geol Sin 91(5):1158-1167

Tang LG, Li XS, Feng ZP, Li G, Fan SS (2007) Control mechanisms for gas hydrate production by depressurization in different scale hydrate reservoirs. Energy Fuels 21(1):227-233

Tissot B, Durand B, Espitalie J, Combaz A (1974) Influence of nature and diagenesis of organic matter in formation of petroleum. AAPG Bull 58:499-506

Vaular EN, Barth T, Haflidason H (2010) The geochemical characteristics of the hydrate-bound gases from Nyegga pockmark field, Norwegian Sea. Org Geochem 41:437-444

Wang T, Liu TJ, Chao LY, Cao DY, Guo JN, Liu YF, Wen HJ, Wang D (2009) Characteristics and origins of the gas hydrates in the Muli coalfield of Qinghai. Coal Geol Explor 37(6):26-30 
Wang PK, Zhu YH, Lu ZQ, Huang X, Pang SJ, Zhang S, Jiang SQ, Li QH, Yang KL, Li B (2014) Geochemistry and genesis of authigenic pyrite from gas hydrate accumulation system in the Qilian Mountain permafrost, Qinghai, northwest China. Sci China Earth Sci 44(6):1283-1297

Wang Y, Feng JC, Li XS, Zhang Y, Li G (2016) Large scale experimental evaluation to methane hydrate dissociation below quadruple point in sandy sediment. Appl Energy 162:372-381

Whiticar MJ (1996) Stable isotope geochemistry of coals, humic kerogens and related natural gases. Int J Coal Geol 32:191-215

Whiticar MJ (1999) Carbon and hydrogen isotope systematics of bacterial formation and oxidation of methane. Chem Geol 161:291-314

Zhang SY, Hao JJ, Jiang TR (1988) A new method for the identification of natural gas types by carbon isotopes of methane and ethane. Geology Press, London

Zhang GX, Liang JQ, Lu JA, Yang SX, Zhang M, Holland M, Schultheiss P, Su X, Sha ZB, Xu HN (2015) Geological features, controlling factors and potential prospects of the gas hydrate occurrence in the east part of the Pearl River Mouth Basin, South China Sea. Mar Pet Geol 67:356-367

Zhang M, Kong T, He Y (2016) Geochemical Characteristics of $\mathrm{C}_{5^{-}}$ $\mathrm{C}_{7}$ light hydrocarbons in gas hydrates from the Permafrost Region of Qilian Mountains. Acta Geol Sin 90(6):2283-2284

Zhu YH, Zhang YQ, Wen HJ, Lu ZQ, Xia ZY, Li YH, Li QH, Liu CL, Wang PK, Guo XW (2009) Gas hydrates in the Qilian Mountain Permafrost, Qinhai, Northwest China. Acta Geol Sin 83(11):1762-1770

Zhu YH, Zhang YQ, Wen HJ, Lu ZQ, Wang PK (2010) Gas hydrates in the Qilian Mountains permafrost and their basic characteristics. Acta Geosci Sin 31(1):7-16

Zumberge J, Ferworn K, Brown S (2012) Isotopic reversal ('rollover') in shale gases produced from the Mississippian Barnett and Fayetteville Formations. Mar Pet Geol 31:43-52 